\title{
Korliki - erään Vahin hantin nykytilanne
}

\section{Johdanto}

Vuoden elokuussa 2006 kävimme vahinhantilaisessa Korlikin kylässä FM Susanna Virtasen ${ }^{1}$ kanssa; oppaanamme toimi FK Zoja Stepanovna Rjabtšikova. Työskentelen valtakunnallisessa kieliaineiden tutkijakoulu Langnetissa tutkijakoulutettavana ja kirjoitan väitöskirjaa itähantin informaatiorakenteesta. ${ }^{2}$ Rjabtšikova työskentelee Jugran yliopiston Ugrilaisten kielten, historian ja kulttuurin instituutissa kielten opiskelun ja keskustelun laboratorion johtajana ja tutkijana, ja hän on järjestänyt erilaisia kielen revitalisaatiotoimintoja kuten kieli- ja kulttuurileirejä hantilaisille. Virtanen taas laatii väitöskirjaa mansin kielen syntaksista.

Matkamme tarkoituksena oli saada yleiskuva hantista; minulla lisäksi saada tietoja Vahin hantin nykytilanteesta sekä kielen että kulttuurin osalta. Itse asiassa alkuperäinen matkani tarkoitus oli tavata Rjabtšikovan informantti, kerätä aineistoa ja tarkentaa kielioppia ynnä muuta, mutta tämä joutui olemaan koko oleskeluaikamme Nižnervartovskissa, sillä paluumatkan helikopteri ei lentänyt huonon sään takia. Loppujen lopuksi matka oli onnistunut: saimme nähdä ja kokea nykypäivän vahinhantilaista elämää. Keräsin sanastoa ja ilmauksia ja tallensin paljon ääninäytteitä. Tässä raportoin yhden hantilaiskylän nykytilanteesta. Nojaudun sekä matkallani saamaani tietoon että Vahin hantin tutkijan Zoja Stepanovna Rjabtšikovan tähänastisilla tutkimusmatkoillaan keräämiin tietoihin. Rjabtšikova itse on pohjoishanti, Tagin alueelta kotoisin.

\section{Matka Korlikiin}

Korliki sijaitsee maantieteellisesti Hanti-Mansian autonomisessa piirikunnassa, Obiin laskevan Vahjoen sivujoen Korlikin varrella, kielitieteellisesti itähantin Vahin murteen alueella. Korliki kuuluu Nižnervartovskin lääniin, jossa on 340000 asukasta. HantiMansian autonomisen piirikunnan suurin kaupunki Nižnervartovsk on perustettu 1960-luvulla, jolloin öljy- ja kaasuvarat otettiin käyttöön. Aiemmin aluetta kutsuttiin Nižeksi. Alue sai kaupungin statuksen vuonna 1972. Tämä lyhyt historia selittänee kaupungin luonteen: rikas, kallis ja uusi kaupunki, joka on perustettu öljy- ja kaasuteollisuutta varten. Ennen matkaamme olin kuullut venäläisiltä, että Nižnervartovsk on Venäjän kallein kaupunki. Toisaalta, vaikka Nižnervartovskin kaupunki on uusi, alueella oli asutusta muinaisajallakin. Rjabtšikovan mukaan arkeologinen ryhmä löysi vanhan asutuksen jälkiä ja neoliittisen ajan työvälineitä vuonna 1969.

1 Virtasen (2006) matkakertomus on julkaistu Alkukoti-lehdessä.

2 Olen saanut tutkijakoulu Langnetista matka-avustuksen tätä matkaa varten. Kiitän tuesta. 
Helsingistä Korlikiin pääsimme seuraavaa reittiä: ensin matkustimme junalla Helsingistä Moskovaan 8. elokuuta. Moskovasta jatkoimme tavallista junaa hienommalla "liikematkajunalla" Nižnervartovskiin; tämä kesti 55 tuntia. Matkan viimeinen osuus oli lento Nižnervartovskin lentokentältä helikopterilla Korlikiin. Venäjän viidenneksitoista suurimmalla Nižnervartovskin lentoasemalla on kotimaan lentojen lisäksi erikseen kansainvälisten lentojen puoli. Siperialaista teollisuuskaupunkia kuvaa mielenkiintoisella tavalla se, että lentoasema on valmistunut vuonna 1965, kun taas ensimmäisen juna tuli rautatieasemalle vasta vuonna 1980. Autonomisen piirikunnan pääkaupungissa Hanty-Mansijskissakaan ei ole rautatieasemaa.

Minä ja Virtanen tapasimme Zoja Rjabtšikovan Nižnervartovskin rautatieasemalla 11.8.2006. Rekistöidyimme ja vietimme yhden yön Nižnervartovskissa ja lähdimme seuraavana päivänä Korlikiin, joka sijaitsee noin 300 kilometriä Nižnervartovskista koilliseen.

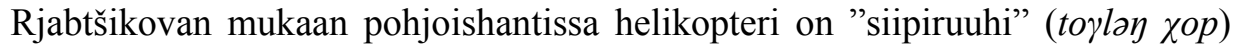
(ks. KT 323-324, 985). Tämä metaforinen ilmaus kuvastaa veneen tärkeyttä hantilaiskulttuurissa ja -elämässä. Nyt perinteisten veneiden lisäksi myös "lentävä vene" toimii tärkeänä kuljetusvälineenä: matkaliput olivat loppuun myytyjä, ja helikopteri oli matkustajien lisäksi täynnä sekä postipaketteja että matkustajien tavaroita. Ikkunasta näkyi ensin moderneja ja korkeita kerrostaloja, mutta pian alkoi näkyä Siperian avara luonto: mutkikkaita jokia, soita, metsiä ja luonnon keskellä pieniä kyliä sekä öljy- ja kaasuteollisuuskenttiä.

Korlikin pienellä lentoasemalla Rjabtšikovan ystävät odottivat meitä. Ihmiset vaikuttivat ystävällisiltä mutta ujoilta. He kantoivat avuliaasti tavaramme internaattiin.

\section{Korliki-kylän elämää}

Asuimme internaatissa koko viikon ja söimme ruokaa emännän, Svetlana Mogultšinan luona. Internaatissa ei lisäksemme ollut paljonkaan ihmisiä kesäloman takia. Emäntämme oli Hanty-Mansijskissa opiskellut lääkäri. Hänen miehensä, venäläinen Aleksi, kertoi olevansa Permistä kotoisin. Hän ei osaa puhua hantia mutta on arkielämässä oppinut jonkin verran ymmärtämään kieltä. Hän näytti sulautuneen hyvin hantilaiskylään ja teki yhteistyötä hantien kanssa. Hän käytteli sujuvasti metsästyksessä hantilaisia työkalujakin. Heillä oli kaksi lasta: esikoinen Angelika, joka opiskeli jo kaupungissa, ja kuopus Nikita, 10-vuotias poika. Oli suuri kunnia, että emäntämme nimitti häntä "miehekseni" - tällä tarkoitetaan lähinnä suomen kummipoikaa. Kyläläisten mukaan kylässä on tapana antaa pojat vanhemmalle naiselle tai vanhemmille naisille "mieheksi", jotta nämä voivat pitää huolta pojasta, mikäli pojan vanhemmille tapahtuisi jotakin. Tytöille ei ole vastaavaa tapaa. Susanna Virtasen "mieheksi" nimitettiin Tima, hantin kielen opettajan poika. "Pikkumiehemme" auttoivat meitä esimerkiksi kantotöissä ja näyttivät meille kylää.

Kylässä kodit on varustettu hyvin. Perheillä on esimerkiksi sellaista elektroniikkaa kuin TV, pakastin, vedenkeitin ja joillakin jopa Playstation-pelikonsoli. Kylässä jopa pienetkin lapset ajavat moottoriveneitä ja -pyöriä. 
Sähkö tuotetaan kylän generaattorilla. Vesijohtoa ei ole, vaan vesi haetaan kaivosta. Pihoilla on pienet kasvimaat, joista saa kesällä tuoreita kasviksia. Ruokaa saadaan kasvimaalla viljelemisen lisäksi kalastamalla, metsästämällä, sienestämällä ja marjojen keruulla. Isäntämme kertoi asuvansa metsästyksen vuoksi koko talven metsässä. Saaliit myydään tai käytetään itse. Saimme häneltä karhun rasvaa tuliaisiksi. Rasva on vedenkirkasta ja hajutonta. Siperiassa karhun rasva on arvotuote: kylän naisten mukaan se on hyvä kosmeettinen aine. "Lisäksi pysymme terveenä, jos syömme lusikallisen karhun rasvaa päivittäin", meille kerrottiin.

Kylä on turvallinen ja siisti, ja kaikki näyttää toimivalta. Kylässä on koulu, päiväkoti ja kirjasto sekä kaksi sairaalaa, joista toinen on poliklinikka. Lääkäri käy Nižnervartovskista säännöllisesti. Kylässä on myös laboratorio, hammaslääkäri, puhelinkeskus, säähavaintoasema, museo, kolme elintarvikekauppaa, internaatti, posti, pankki, apteekki, lähinnä suomalaista huoltoasemaa vastaava "asunto-oloorganisaatio" ja lentokenttä. Suuri osa näistä on uusia ja moderneja. Rjabtšikovan mukaan kylässä oli ollut myös oma hallinto vuoteen 2005 asti, koska aiemmin jokaisessa kylässä oli sellainen, mutta nykyään hallintoyksikköjä on vain yksi muutamaa kylää kohti. Nyt lähin hallintopiste sijaitsee Larjakissa, joka sijaitsee noin 130 kilometriä Korlikista koilliseen.

Vaikka kylässä olisi kuinka paljon tilaa, melkein kaikki kyläläiset asuvat keskustassa tiiviisti. Elämä Siperiassa on rankkaa ja kovaa, joten ihmiset haluavat asua lähekkäin ja palvelujen lähellä. Jo helikopterista näimme, että Korliki on metsän keskellä oleva eristynyt ja suljettu maailma. Myöhemmin kuulimme, ettei kylässä ollut juurikaan käynyt ulkomaalaisia lukuun ottamatta paria henkilöä, joiden nimet kyläläiset muistavat. Edes K. F. Karjalainen tai H. Paasonen eivät olleet käyneet tässä kylässä. Kylässä asuu noin 500 asukasta, joista noin 400 on hanteja.

Rjabtšikovan mukaan aikaisemmin kylä oli lähempänä Vahjokea. Vanhassa kylässä oli vain asuntoja, mutta nykyiseen paikkaan tuli kolhoosi ja samalla julkisia palveluja.

Monet paikat kuten kylän kirjasto olivat kiinni kesälomalla. Kävimme kuitenkin kylän muutamissa julkisissa paikoissa. Puhelinkeskusta tarvitaan, koska kylässä ei ole matkapuhelimille antennia eikä ihmisten kodeissa ei ole lankapuhelimia, vaikka puhelinkeskuksessakaan yhteys ei ole kovinkaan hyvä. Puhelinkeskus, pankki ja posti ovat samassa pienessä talossa, mutta näillä on erilliset ovet.

Museo oli remontin takia suljettu mutta avattiin meitä varten. Museon eteisessä on kaksi kylttiä - toinen venäjäksi, toinen hantiksi. Hantinkielisessä kyltissä lukee wertə kat, "tekevä talo, työpaja". Museossa on mukavasti näytteillä muun muassa hantien käsitöitä, talo, reki ja leipäuuni. Pyysin museon johtajaa Tatjana Fjodorovna Katkalevaa opastamaan meitä hantiksi. Tietoja hänellä riittikin, sillä hän on julkaissut esimerkiksi pienen Vahin hantin sanakirjan sekä oppikirjan.

Myös koulun eteisessä on kahdella kielellä kyltit. Hantinkielisessä kyltissä lukee

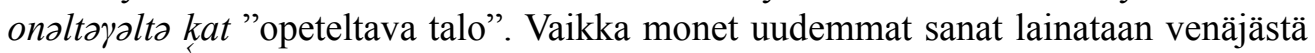
suoraan hantiin (esimerkiksi Surgutin hantissa 'koulu' on suora laina, škola), tarkoituksena on ilmeisesti keksiä hantilaisia ilmauksia. Koulu täytti 75 vuotta vuonna 2005, ja se on näin ollen Nižnervartovskin läänissä vanhin, vaikka rakennukset ovat 
uusia, vain kaksi vuotta sitten rakennettuja. Koulun johtaja on venäläinen nainen, jolla on hantilainen mies. Koulussa on 20 opettajaa (lukuun sisältyvät osa-aikaiset opettajat) ja noin 120 oppilasta. Siellä opetetaan hantin kieltä; sitä varten on erikseen luokkakin, jossa on esillä hantilaisia käsitöitä ja pienoisesineitä kuten reki, kota ja tuohikori. Luokan ovessa, kuten muidenkin luokkien ovessa, on hantilaisilla ornamenteilla koristettu kyltti. Uuttakin hantin kielen oppimateriaalia tuotetaan, ja tämä materiaali on käytössä tunneilla. Korlikissa hantin kielen opetusta on kaksi kertaa viikossa 1-2-luokkalaisille, kerran viikossa 4-6-luokkalaisille. Vanhemmille oppilaille ei pidetä hantin kielen tunteja.

Kävimme myös koulun kirjastossa. Pyysin kirjastonhoitajaa näyttämään hantinkielisiä kirjoja, mutta kirjastossa hantiin liittyviä kirjoja on vain neljä kappaletta. Näistä kaksi on aapisia ja loput venäjänkielisiä hantilaisesta kulttuurista kertovia kirjoja. Koulun kirjastonhoitaja on myös hanti, jonka äiti P. F. Merkulova oli ensimmäisen Vahin hantin aapisen tekijä. Hän on myös julkaissut museon johtajan T. F. Katkalevan kanssa pienen sanakirjan vuonna 1995 sekä N. I. Terjoškinin ja T. F. Katkalevan kanssa sanakirjan vuonna 1999.

Matkamme aikana opetimme koulussa kyläläisille japania ja suomea, ja hantin opettaja Svetlana Prasina antoi vähän hantin opetusta kaikille. Opintopiiriimme tuli sekä lapsia että aikuisia. Kaikki olivat ahkeria ja innokkaita oppimaan uusia kieliä. Hantien keskuudessa on yleistä, että kieltä puhutaan hyvin mutta lukutaito puuttuu. Aikuiset opiskelivat ahkerasti äidinkieltään kanssamme. Lapset opiskelivat vielä kotonakin japania ja suomea ja yrittivät heti käyttää tunneilla opittuja sanoja ja ilmauksia. Oli hauskaa nähdä, että hantilaisilla suomen kielen lukusanat 1-6 sujuivat todella hyvin. Siitä eteenpäin oli kuitenkin vaikeampaa - syystäkin, sillä Vahin hantiksi lukusanat 1-6 kuuluvat ej, kätkan, kolam, ńela, wet, kut mutta lukusanat 7-10 läwat,

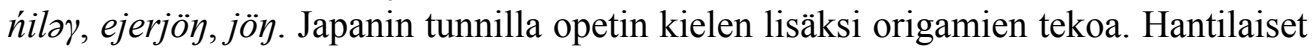
olivat ihmeen taitavia. Eräs heistä löysi itse ratkaisut, miten kuvio taitetaan - vain katsomalla valmiiksi taitettuja esineitä. Tuntien jälkeen Rjabtšikova teki tutkimustöitä kylän naisten kanssa.

\section{Kylän ongelmia}

Vaikka kylä näyttää turvalliselta ja ihmiset näyttävät onnellisilta, ongelmiakin on. Kylässä on esimerkiksi paljon työttömiä. Aikaisemmin kolhoosi tarjosi työtä, mutta sen päätettyä toimintansa moni jäi työttömäksi. Rjabtšikovan tiedon mukaan vuonna 2003 koko Hanti-Mansian autonomisessa piirikunnassa oli noin 4000 hantia työttömänä ja noin 1000 hankki elantonsa itsenäisesti muun muassa luontaistaloudella. Korlikissa oli noin 50 henkeä työttömänä, näistä suuri osa miehiä. Kylässä oli kuulemamme mukaan alkoholiongelmiakin, erityisesti miehillä, mutta en itse nähnyt kylässä yhtään alkoholiongelmaista. Rjabtšikovakaan ei ollut nähnyt useiden käyntien aikana tällaista.

Toinen ongelma on nuorison tulevaisuus. Nuoret lähtevät kylästä kaupunkiin, esimerkiksi opiskelemaan. Jotkut heistä palaavat kylään, mutta moni jää kaupunkiin. Nuorisoa yritetään houkutella jäämään tai tulemaan takaisin kylään, mutta tämä on 
vaikeaa, koska kylässä ei ole töitä. Houkuttimeksi annetaan jopa palkinto, n. 50000 ruplaa ja oma koti, jos jää kylään.

Yritin miettiä, eikö löytyisi mitään lisäideoita kylän tulevaisuuden pelastamiseksi. Löysin internetistä mainoksen turistimatkasta Korlikiin. Ensisilmäyksellä ajatus vaikutti hyvältä: Vahin joen ranta on kauniin valkoinen hiekkaranta, ja kylässä on hyvä museokin! Mutta Rjabtšikovan mukaan nykyään Venäjän maaseudulla turismi on ollut jonkinlainen buumi, jossa melkein kaikki ovat epäonnistuneet. Valitettavasti sama kohtalo oli tällä yrityksellä Korlikissa.

Kolmas ongelma on elintarvikkeiden puute. Kävimme yhdessä elintarvikekaupassa, joka on suurin kolmesta. Se oli silti pieni. Yksi kyläläisten ongelmista onkin se, että ihmiset kaipaavat muitakin tavaroita. He joutuvat käymään Nižnervartovskissa, mutta matkalippu on kallis.

\section{Kielen tilanne}

Korlikissa monia kenttätöitä tehnyt Rjabtšikova vakuuttaa, että kaikki kylän hantit, mukaan lukien lapset, osaavat hantia. Hän uskoo hantin kielen tulevaisuuteen kylässä niin paljon, että täällä hänen mukaansa tullaan puhumaan hantia, vaikka muualta hantin kielen käyttö häviäisikin. Naapurikylässä Larjakissa, joka on tämän alueen keskus, on vain kaksi puhujaa ja hekin puhuvat venäjää arkielämässään. Kuten monia muita vähemmistökieliä, hantia ei enää puhuta kaupungeissa. Kyläläisten mukaan kieli säilyy Korlikissa hyvin sen takia, että kylä on oma eristynyt ja suljettu maailmansa.

Kylässä puhutaan siis hantia. Lapset osaavat hantia mutta puhuvat kuitenkin usein keskenään venäjää, erityisesti kun läsnä on venäjänkielisiä lapsia. Toisaalta myös venäjänkieliset lapset osaavat hantia vieraana kielenä. Perheen sisällä puhutaan usein hantia, toisinaan sekaisin venäjän kanssa. Aikuiset puhuvat keskenään hantia ja venäjää sekoitettuna: keskustelu voi esimerkiksi alkaa hantin kielellä, välillä joku voi puhua venäjää, joku voi vastata hantiksi siihen. Se puhuja, joka äsken puhui venäjää, voi taas puhua hantia ja niin edelleen. Näyttää siltä, että vanhat ihmiset puhuvat paremmin hantia kuin venäjää ja kyläläiset puhuvat hantia vanhojen ihmisten kanssa. Kalassa miehet puhuivat hantia keskenään, vaikka läsnä oli yksi venäjänkielinen. Lisäksi venäjänkieliset käyttävät hantista lainattuja sanoja venäjänkielisessä keskustelussa; esimerkiksi yksi venäjänkielinen poika sanoi äidilleen: Mama, možna ńan! - Sana ńan tarkoittaa hantiksi leipää. Poika käyttää puheessa myös weli-sanaa, joka tarkoittaa hantiksi poroa.

Emäntämme lisäksi myös koulun hantin kielen opettaja Svetlana Prasina opetti minulle Vahin hantin sanoja ja ilmauksia. Oleskelumme loppuvaiheessa opettajan poika Tima oli omaksunut äitinsä tavan ja opetti ylpeästi minulle sanoja hantiksi.

Yleisesti "hantiksi” kutsuttujen kielimuotojen sisäiset erot ovat suuria. Kylän toinen lääkäri Oksana puhuu Vahin hantia ja hänen miehensä taas Surgutin hantia äidinkielenään. He joutuvat puhumaan venäjää keskenään, koska Surgutin ja Vahin hanti ovat niin erilaisia, etteivät puolisot ymmärrä toisiaan. Tämä on yksi hyvä käytännön esimerkki hantin kielten erilaisuudesta, jopa itähantin sisällä. Kielellisten erojen lisäksi luonto on eri alueilla erilaista. Kuten K. F. Karjalainen kirjoitti jo yli sata 
vuotta sitten, Vahin alueen maaperä on köyhää ja hiekkaista, kun taas pohjoishantin alueella maaperä on rikas. Käsityömestari Žanna A. Hohljankina vitsaili, että hänen olisi pitänyt ottaa mukaan kotieläinten ulosteita lannaksi kotiin, kun hän kävi siellä Rjabtšikovan synnyinkylässä, Tagissa. Vaikka Tagissa kukaan ei kiinnittänyt huomiota ulosteisiin ja ulosteet jätetään käyttämättä, Korlikissa niitä kerätään ja käytetään kasvimaan lannoitteena. Maaperän erojen lisäksi itähantin alueella on öljy- ja kaasukenttiä, kun taas pohjoishantin alueella ei ole. Tämä on ilmeisesti kaksipiippuinen seikka: Rjabtšikovan mukaan pohjoisessa säilyy paremmin kieli ja kulttuuri, mutta läänissä ei ole paljon varallisuutta. Idässä alkuperäiskansojen kieli ja kulttuuri ovat teollistumisen takia vakavasti uhanalaisia, mutta läänissä on sen verran rahaa, että kaupunki tukee taloudellisesti alkuperäiskansojenkin elämää ja rakentaa palveluja kyliin.

\section{Perinne ja kulttuuri}

Vaikka ajatellaan, että itäisellä hantilaisalueella säilyy vähemmän hantilaista kulttuuria ja kieltä kuin pohjoisessa, Korlikissa perinne elää ihmisten elämässä. Käsityöt ovat hyvin yleisiä täällä, ja ihmiset ovat taitavia. Täällä käytetään arkipäiväisesti tuohikoreja ja astioita. Nämä ovat hyvin kestäviä, ja niitä voi esimerkiksi pestä. Rjabtšikovan mukaan suuri osa kylän naisista osaa tehdä hyvin tuohitöitä. Kylän naisista Žanna A. Hohljankina on rekisteröity tuohimestariksi kaupunkiin. Hänen kotinsa pihalla on lawas 'hantilainen varasto' (ks. KT 1081), tontəy kat 'tuohikota' (KT 357-358, 1005). Hän käyttää kotaa, kun tekee käsitöitä ja tuohitöitä, joihin tarvitaan tulisijaa. Hän tuntee hyvin perinteistä hantikulttuuria ja kertoi erilaisista hantilaisista esineistä hantiksi.

Miehetkin tekevät töitä käsin. - He tekevät itse esimerkiksi veneitä ja airoja. Veneet ovat sekä metallisia että puisia. Vene on tärkeä kulkuväline kyläläisille. Eräs mies sanoi, että hän matkusti Nižnervartovskiin asti veneellä ja hänen matkansa kesti noin kolme päivää. Samaten kalastus on edelleenkin tärkeää hantilaisille. Kalastus tapahtuu ryhmässä. Kalat käsitellään heti pyydystämisen jälkeen. Naiset laittavat kalat vatiin ja poistavat suomut ja sisukset. Täynnä kalaa oleva vene sekä perkaamistöissä olevat naiset näyttävät samanlaisilta kuin vanhoissa valokuvissa. Kalojen sisuksia ei kuitenkaan heitetä pois, vaan ne hyödynnetään. Sisuksista otetaan rasvaa ( $k u l$ woj 'kalan rasva') (KT 6-7, 380). Rasva on sekä syötäväksi että nahan parkitsemiseen, okni woj '(syötävä) kalan rasva' ja pəkwa 'kalan rasva (parkitsemista varten)'.

Jernas-kansallispukua on nähty harvoin kylässä, mutta 70 -vuotias rouva Risa Petrovna vaihtaa aina jernas-pukuun, kun hän lähtee johonkin kotoa. Rouva näytti muun muassa tekemiään kauniita hantilaisia saappaita, laukkuja ja erilaisia kansallispukuja.

Luontouskonto elää vielä ihmisten elämässä. Kun hanti menee keväällä veneeseen vuoden ensimmäistä kertaa, hänen täytyy kastella viidesti päätään joen vedellä, jotta vedenhaltija suojelisi häntä. Ihmiset tekevät kuin luonnostaan näin, ja itse tein samoin. Vahjoen varrella on viisi pyhää paikkaa, joihin heitetään kolikoita ja joissa sidotaan kangaspaloja puihin. Pyhissä paikoissa ei saa valokuvata, ja joihinkin pyhiin 
paikkoihin eivät naiset pääse. Tällä kertaa kävimme vain sellaisissa pyhissä paikoissa,

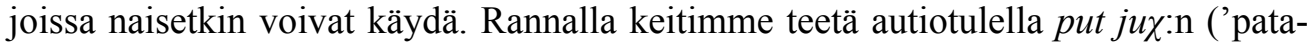
puu') (KT 761) avulla, joka on koukistuneesta puusta tehty keittotanko. Samalla äänitin 70-vuotiaan rouvan juttuja.

Kylässä on eräs mielenkiintoinen kulttuurihenkilö. Tämä rouva on erinomainen laulaja ja lauluntekijä. Hän esitti meille hantilaisia lauluja kahden muun naisen kanssa, kerhossa (wertə kat). Laulamisen lisäksi hän kerää kylän satuja, anekdootteja ja historiaa ja kirjoittaa niitä muistiinpanoiksi. Esityksen jälkeen haastattelin häntä hieman ja hän näytti näitä vihkoja. Valitettavasti minulla ei ollut tarpeeksi aikaa saada tietoja hänen elämäntyöstään; tämäkin jäi tulevaisuuden työksi.

\section{Lopuksi}

Olen lingvisti ja saan kyläläisiltä tietoja tutkimusta varten. Aina matkan jälkeen ajattelen, mitä voisin palauttaa paikallisille. Näyttää siltä, että ulkopuolisten ihmisten vierailu näiden hantien kylässä ja se, että heidän kieltään ja kulttuuriaan tutkitaan, vaikuttaa positiivisesti heidän identiteettiinsä. Rjabtšikova kertoi kokeneensa niin, että positiivinen vaikutus on kuitenkin yleensä lyhytaikainen, joten meidän täytyy olla sinnikkäitä. Zoja Rjabtšikova ja edesmennyt Éva Schmidt ovat omistautuneet paljon Korlikin kylälle. He ovat tietoisesti pohtineet, mitä he voivat tehdä yhdessä, ja toimineet sen mukaan. Rjabtšikovasta tuntuu siltä, että hän on Schmidtin työn jatkaja. Hän järjestää kieli- ja kulttuurileirejä eri puolilla hantien aluetta. He onnistuivat kielen ja kulttuurin säilyttämiseen tähtäävässä koeprojektissa. Siitä lähtien Rjabtšikova on käynyt monta kertaa kylässä, kerännyt satuja, rohkaissut ihmisiä ja ystävystynyt kyläläisten kanssa. Rjabtšikovan ansiosta me, jotka kävimme kylässä ensimmäistä kertaa, pääsimme sisään, ja itse keräsin materiaalia ja saan jatkossakin kerätä.

\section{Viitteet}

KT = Karjalainen, K. F. \& Toivonen, Y. H. 1948: Ostjakisches Wörterbuch. Lexica Societatis Fenno-Ugricae X. I-II. Helsinki: Suomalais-Ugrilainen Seura.

Virtanen, Susanna 2006: Satumainen Siperia. - Alkukoti 8/2006: 29-31.

Sachiko Sosa <sachiko.toguchi@helsinki.fi>

Suomalais-ugrilainen laitos

PL 25

00014 Helsingin yliopisto 